\title{
Statistical Report Record
}

National Cancer Institute

\section{Source}

National Cancer Institute. Statistical Report Record. NCI Thesaurus. Code C115571.

Records pertaining to the statistical data from a clinical trial. 